\title{
LABOUR AND WEATHER RELATED RISKS IN SMALLHOLDER RUBBER PRODUCTION: EVIDENCE FROM KALUTARA DISTRICT
}

\author{
Waduge TD, Edirisnghe JC*, Fernando APS, Herath HMLK, Jayasinghe-Mudalige UK \\ Dept. of Agribusiness Management, Faculty of Agriculture and Plantation Management, Wayamba University \\ of Sri Lanka, Makandura, Gonawila
}

Accepted: 12 March 2014

\begin{abstract}
It was observed that even in the times of higher prices some smallholder rubber producers remain poor. The reason for this variation in income is thought to be risks associated with rubber production. Therefore, this study investigated the risks related to labour and weather taking a sample of 500 smallholder farmers from the Kalutara district. A Just and Pope stochastic production function is estimated using a three step Feasible Generalized Least Square (FGLS) technique. The estimated variance equation reveals that rainfall and labour usage are risk increasing while price is risk reducing. Weather (rainfall) is typically believed to be the primary source of loss in potential income. Although, results show that this is true based on the sign of expected coefficients, they failed to show statistical significance. However, variability of labour and rubber price showed statistical significance. It is therefore envisaged that availability of farm labour is a key issue in production risk, which is not given due consideration in policy.
\end{abstract}

Key words: Weather, Just and Pope Production Function, Risk, Feasible Generalized Least Squares

\section{INTRODUCTION}

Today, Sri Lanka's rubber industry consists of two closely interdependent sectors: the plantation industry, and the rubber products manufacturing industry. Rubber plantation sector consist of two sub sectors: Estate and the small holding sector. In Sri Lanka total rubber extent is 125,645 ha with a total production of $157,900 \mathrm{MT}$, out of which 107, 200MT are used in local consumption while $51,500 \mathrm{MT}$ are exported. Total export earnings are in the order of Rs. 83224 million (Central Bank, 2011).Contribution by the smallholding sector to national production is immense. Sixty three percent of the national production comes from the rubber smallholders. Average yield of small holding sector is $1719 \mathrm{~kg} \backslash$ ha. Yet the majority of rubber smallholders are still poor in Sri Lanka, In spite of the fact that the world rubber prices are significantly high (Wimalagunasekara et al 2012; Kumarasinghe, et al 2012). For example, the annual average price of Ribbed Smoked Sheets (RSS) No 1 recorded a very high price of Rs. 509 per kilogram in 2011 (Central Bank, 2011). One reason

\footnotetext{
*Corresponding author: jagathed@yahoo.com
}

can be the variation in income they receive due to variation in the output theyobtain. This variation is termed as risk. It ishypothesized that this variation arises from two sources: weather and inputs used. Here an attempt is made to isolate and estimate such effects, taking rainfall (weather) and labor (inputs) intoaccount.Rainfallis taken because it is the primary weather factor that affects rubber production. Annual average of rainfall over Sri Lanka has been decreased by an amount of 144 millimeters, about seven percent, during 1961 to 1990 period compared to 1931 to 1960 period (Chandrapala, 1996). The downward trend in recent decades is found to be steeper than the longer variations (Jayawardene, et al., 2005). Labor is used for similar reasons: it is the most required input in operating a rubber estate. Further, Laborers constitute a vital input in agricultural production, but they are migrating to different parts of the country for earning a better livelihood, adding to the existing imbalance between demand and supply of laborers(Deshingkar, 2003; Anon, 2013). 


\section{METHODOLOGY}

Data for the study comes from both primary and secondary sources. For the collection of primary data 500 smallholder rubber farmers in the Kalutara district were interview. Kalutara district is selected because it is one of the major rubber growing districts in the country and because it being a traditional rubber growing region both input and output markets are well developed. Kalutara has an extent of 29,299 hectares of rubber which is around 23 percent of total rubber extent in the country (Anon, 2010). There are about 33,598 farmers who grow rubber and the extent of smallholder rubber cultivation in the area is around 19058. There is a remarkable weather variation within the district, which suits our study well. There are 14 Divisional Secretariat (DS) divisions in the Kalutara district. The sample of 500 farmers was weighed among these 14 DS divisions as;

Sample Size per $=\underline{\text { No. of small holders in DS divisionj }} * 500$ DS division $\quad$ No. of small holders in the district

The selection of farmers to be interviewed was carried out by randomly selecting from a list of farmers using a random number table. Interviews were carried out by using a pretested structured questionnaire. Data collection was carried out during the months of May - June 2012.

Table 1: Description of variables included in the analysis

\begin{tabular}{|c|c|}
\hline Variable & Description \\
\hline $\begin{array}{l}\text { Mean } \\
\text { Rainfall }\end{array}$ & Average rainfall received \\
\hline $\begin{array}{l}\text { CV Rain- } \\
\text { fall }\end{array}$ & Coefficient of variability of Rainfall \\
\hline $\begin{array}{l}\text { CV labor } \\
\text { cost }\end{array}$ & Coefficient of variability of cost of labor \\
\hline CV Price & Coefficient of variability of \\
\hline Extent & Extent cultivated \\
\hline $\begin{array}{l}\text { Family } \\
\text { Labor }\end{array}$ & Number of family laborers used \\
\hline $\begin{array}{l}\text { Hired } \\
\text { Labor }\end{array}$ & Number of labor hired \\
\hline Fertilizer & Amount of fertilizer applied \\
\hline
\end{tabular}

Secondary data on weather (climate) from the Department of Meteorology in Sri Lanka was collected to be used in the analysis. The main interest was to assess the impact of climate and main factors of production related to rubber cultivation. Therefore, variables as described in Table 1 were included in the analysis.

\section{Analytical Framework}

Consider a Rubber Smallholder household involved in the production of output y. The Rubber Production is represented by the production function,

$y=g(x, v)$ where $\mathrm{y}=$ output, $\mathrm{x}=$ vector of controllable inputs, $\quad \mathrm{v}=$ vector of uncontrollable inputs, $\mathrm{g}(\mathrm{x}, \mathrm{v})=$ denotes the largest feasible output given $\mathrm{x}$ and v (Di Falco et al., 2007).

As the interest of this research is in measuring the impact on the risks (variation) of output, thefocus was on the scale of production uncertainty as represented by the stochastic production function, $y=g(x, v)$. The specification by Just and Pope (1978) which followed here is:

$y=g(x, v)=f(x, \beta)+[h(x, \theta)]^{1 / 2} \varepsilon$

Where $\quad h(x)>0$ and $\varepsilon$ is a random variable with mean zero and variance 1 . Accordingly, the production function is composed of two components; the mean or the deterministic component, $f(x, \beta)$ and the variability component, $h(x, \theta)$. Thus, $E(y)=f(x, \beta)$ and $\operatorname{var}(y)=$ var $(\varepsilon) h(x, \theta)=h(x, \theta)$. Just and Pope developed this production model and its properties with emphasis on its flexibility with respect to impact of inputs on the variance of output (Farnsworth and Moffitt, 1981).

Because, $\partial \operatorname{var}(y) / \partial x=\partial h / \partial x$, it follows that $\partial h /$ $\partial x<0$ identifies covariates that are risk decreasing, while $\partial h / \partial x>0$ identifies covariates that are risk increasing (Di Falco et al., 2007). The component $[h(x, \theta)]^{1 / 2} \varepsilon$ behaves like an error term with a mean of zero and a variance $h$ $(x, \theta)$. This reflects the fact that the Just - Pope specification corresponds to a regression model with a heteroscedastic error term.

Several econometric procedures have been developed to correct for heteroscedasticity in such cases. Following Just and Pope (1979), a Multi stage Non-linear Least squares (MNLS) 
estimation procedure can be applied to generate consistent and asymptotically efficient estimates of the parameters of the stochastic production function in equation 1. Amultistage linear least squares estimation procedure that involves three steps proposed by Hurd (1994) was followed.

\section{Estimation Strategy:}

In the first step the empirical specification of the model was estimated and use dthe ordinary least squares (OLS) to obtain consistent estimates of $\hat{\beta}$ and $\hat{u}$ from the regression of $\mathrm{y}$ on $f(x, \beta)$ and the residual, $\hat{\mathrm{u}}$ was calculated as:

$$
\hat{u}=y-f(x, \hat{\beta})=\hat{h}(x, \theta) \varepsilon \text { or } \hat{u}=\ln y-\ln f(x, \hat{\beta})
$$

In the second step, the estimated residues $\hat{\mathrm{u}}$ were squared and transformed by taking natural logarithms. These transformed values were then regressed on the covariates to obtain consistent estimates of $\hat{\theta}$

In the final step, the estimates of $\hat{\theta} \mathrm{w}$ e $\mathrm{r} \mathrm{e}$ used to construct a feasible generalized least squares estimate $\hat{\beta}$ that is both consistent and efficient. To do so a weighted least square regression of $y^{*}$ on $f^{*}$ $(x, \beta)$ or $\ln y^{*}$ on $\ln f(x, \beta)^{*}$ was carried out where,

$$
\begin{gathered}
y^{*}=\frac{\ln y}{h^{1 / 2}(x, \hat{\theta})}, f^{*}=\frac{f(x, \beta)}{h^{1 / 2}(x, \hat{\theta})} \\
y^{*}=\frac{\ln y}{\frac{1}{2} \ln h(x, \hat{\theta})}, f^{*}=\frac{\ln f(x, \beta)}{\frac{1}{2} \ln h(x, \hat{\theta})}
\end{gathered}
$$

If the function $\mathrm{y}=f(\mathrm{x}, \beta)$ is heteroscedastic, the predicted values of the residuals from the regression on the explanatory variables will enable to capture the values of the residuals related to these variables (Fufa and Hassan, 2003). The weighting of this function by the predicted values of the residues from equation
2 will give consistent and asymptotically efficient parameter estimates of the function. Data analysis was carried out using STATA (Version 11.0).

Because rainfall is a key weather variable that affects the variation in the rubber yield that variable was included in the variance function. Similarly, as rubber tapping is a heavy labor intensive activity, it was hypothesized that labor also is a key variable that is related with yield risk. Additionally, output price of rubber to assess the price risk on yield variance was incorporated. As the objective was to find how variability in these variables is related with the variation in yields, Coefficient of Variability (CV) of these was incorporated. $\mathrm{CV}$ is calculated as,

$\mathrm{CV}=($ Mean/Standard Deviation $)$

\section{RESULTS AND DISCUSSION}

The results of FGLS mean and variance equations are given in Table 2. Coefficient estimates, their standard errors, calculated ' $t$ ' values and the corresponding probabilities are reported. It is to be noted that a variable with a positive sign increases yield variability while a variable with a negative sign reduces it. Except the $\mathrm{CV}$ of price, all other variables are found to be risk increasing. This indicates that when the price variability increases, variability in production in the data set reducers. During the time of data collection, price of rubber is soaring in the market. Therefore, smallholders are expecting the prices to rise further. Therefore, price may be a risk reducing factor, as farmers' expectation towards price is favorable.

Although, rainfall is expected to have a marked influence on yield variability, neither the mean rainfall nor its variance shows significance. Nevertheless, this may be a data issue. Because of unavailability of rainfall data where farms are located, time series data 
on rainfall on the nearest rainfall station was used to predict the rainfall on the farm for the period of data collection. However, variability in labour usage shows a positive and significant coefficient. Therefore, for the present data set, labour is more risk increasing than the primary weather factor, rainfall.

Table 2: Parameter estimates from the FGLS Variance Equation and Mean Equation

\begin{tabular}{|c|c|c|c|c|}
\hline Variable & $\begin{array}{c}\text { Coeffi- } \\
\text { cient }\end{array}$ & $\begin{array}{c}\text { Std } \\
\text { error }\end{array}$ & $\mathrm{T}$ & $\mathrm{P}$ \\
\hline \multicolumn{5}{|c|}{ Variation Equation } \\
\hline $\begin{array}{c}\text { Mean } \\
\text { Rainfall }\end{array}$ & 0.00052 & 0.002 & 0.025 & 0.799 \\
\hline $\begin{array}{l}\text { CV Rain- } \\
\text { fall }\end{array}$ & 1.517 & 1.328 & 1.14 & 0.254 \\
\hline $\begin{array}{l}\text { CV labor } \\
\text { cost }\end{array}$ & 0.345 & 0.145 & 2.37 & 0.018 \\
\hline CV Price & -3.323 & 0.771 & $(-4.31)$ & 0.000 \\
\hline Constant & 8.19 & 1.564 & 5.24 & 0.000 \\
\hline \multicolumn{5}{|c|}{ Mean Equation } \\
\hline Extent & 56.762 & 11.463 & 4.95 & 0.000 \\
\hline $\begin{array}{l}\text { Family } \\
\text { Labour }\end{array}$ & 19.530 & 6.422 & 3.04 & 0.003 \\
\hline $\begin{array}{l}\text { Hired } \\
\text { Labour }\end{array}$ & 42.750 & 12.497 & 3.42 & 0.001 \\
\hline Fertilizer & 0.051 & 0.043 & 1.2 & 0.230 \\
\hline Constant & -37.585 & 30.632 & -1.23 & 0.021 \\
\hline
\end{tabular}

All input variables in the mean production function was significant except fertilizer. This is as expected because there is very limited usage of fertilizer in mature rubber plantations especially at the smallholder level. The highest marginal effect on yield is obtained by the rubber extent, ceteris paribus. The analysis differentiated between family labour and hired labour and it was found that marginal effect of hired labour to be higher than family labour. Because latex extraction is a skilled job, using skilled hired labour may increase yields.

\section{CONCLUSION}

This study aimed at evaluating labour and weather related risks in production of natural rubber by smallholder farmers. Results indicated that rainfall (weather) and labour input increase variation in the rubber production and therefore is risk increasing factors. Because the variability in labour increases risk in output it is prudent for policy makers to attempt maintenance of constant supply of labour. This might entail provision of training and extension services to increase skills of labour as well as maintaining an adequate level of wages to ensure village labour to engage in rubber tapping. To combat the impact of rainfall on production risk, vital is the further expansion of present programmes to promote rain guards for rubber trees.

\section{ACKNOWLEDGEMENT}

Authors gracefully acknowledge the financial support provided by the National Science Foundation of Sri Lanka under the research grant NSF/SS/2011/01.

\section{REFERENCES}

Anon (2010) Plantation Sector Statistical Pocket Book. Ministry of Plantation Industries, Colombo, Sri Lanka

Anon (2013) Sri Lanka Plantation Workers win 18-pct Wage hike.The Sri Lankan Rubber Industry, Downloaded at: http://slrubberindustr y.com/page/2/ (Accessed: 01 January 2014).

Central Bank of Sri Lanka 2011 Annual Report, Central Bank of Sri Lanka, Colombo

Chandrapala, L. (19960 Long term trends of rainfall andtemperature in Sri Lanka. In: Climate variability and agriculture, eds., Abrol, Y. P.; Gadgil, S.; Pant, G. B. (eds). New Delhi, India: Narosa Publishing House

Deshingkar, P. (2003) Improved Livelihoods in Improved Watersheds: Can MigrationBe Mitigated? In "Watershed Management Challenges: Improving Productivity, Resources and Livelihoods International Water ManagementInstitute, Colombo. http://www.odi.org.uk/ 
p 1 a g / R E S O U R C E S / books/05_priya_migration_mitigation.p df

Di Falco S, Chavas JP, Smale M. (2007) Farmer management of production risk on degraded lands: the role of wheat variety diversity in the Tigray region, Ethiopia. Agricultural Economics, 36: 147-156

Farnsworth, R. L., and Moffitt, L. J., (1981) Cotton production under risk: an analysis of input effects on yield variability and factor demand. Western Journal of Agricultural Economics, 155-163.

Fufa, B and Hassan, R.M. (2003) Stochastic maize production technology and production risk analysis in Dadar district, East Ethiopia. Agrekon, 42 (2) 116-128

Jayawardene, H. K. W. I., Sonnadara, D. U. J., \& Jayewardene, D. R. (2005) Trends of rainfall in Sri Lanka over the last century. Sri Lankan Journal of Physics, 6, 7-17.

Just, R. and R.D. Pope 1979 Production Function Estimation and Related Risk Considerations,American Journal of Agricultural Economics 61, 277-84

Kumarasinghe, H, Edirisinghe, J.C. and Patalee, B (2012) Role of human capital in technical efficiency increases: Evidence from a data envelopment analysis of rubber smallholdings in Gampaha district, Journal of the Rubber Research Institute of Sri Lanka. 92, $12-21$

Wimalagunasekara, T.U., Edirisinghe J.C., and Wijesuriya, W., (2012) Neighbours' Influence on Farmer Adoption of Fertilizer Recommendations in Rubber Cultivation: Evidence from a Bayesian Spatial Autoregressive Probit Model Journal of Rubber Research 15(3) 